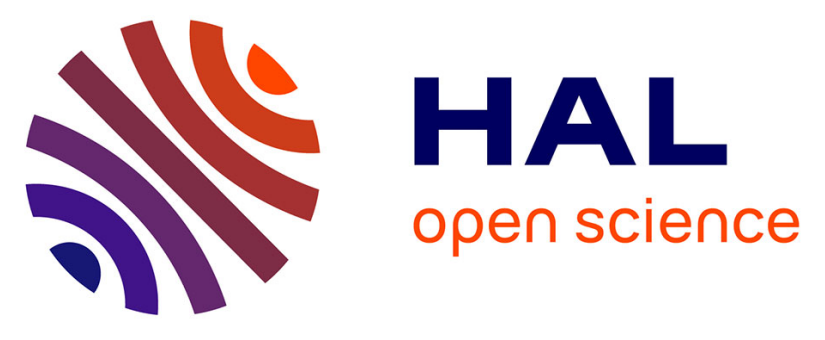

\title{
Emission of Carbonyl and Polyaromatic Hydrocarbon Pollutants From the Combustion of Liquid Fuels: Impact of Biofuel Blending
}

Philippe Dagaut, Yuri Bedjanian, Guillaume Dayma, Fabrice Foucher, Benoit Grosselin, Manolis Romanias, Roya Shahla

\section{To cite this version:}

Philippe Dagaut, Yuri Bedjanian, Guillaume Dayma, Fabrice Foucher, Benoit Grosselin, et al.. Emission of Carbonyl and Polyaromatic Hydrocarbon Pollutants From the Combustion of Liquid Fuels: Impact of Biofuel Blending. ASME Turbo Expo 2018: Turbomachinery Technical Conference and Exposition, 2018, Oslo, Norway. 10.1115/GT2018-75136 . hal-01893662

\section{HAL Id: hal-01893662}

\section{https://hal-univ-orleans.archives-ouvertes.fr/hal-01893662}

Submitted on 4 Mar 2019

HAL is a multi-disciplinary open access archive for the deposit and dissemination of scientific research documents, whether they are published or not. The documents may come from teaching and research institutions in France or abroad, or from public or private research centers.
L'archive ouverte pluridisciplinaire HAL, est destinée au dépôt et à la diffusion de documents scientifiques de niveau recherche, publiés ou non, émanant des établissements d'enseignement et de recherche français ou étrangers, des laboratoires publics ou privés. 


\title{
EMISSION OF CARBONYL AND POLYAROMATIC HYDROCARBON POLLUTANTS FROM THE COMBUSTION OF LIQUID FUELS: IMPACT OF BIOFUEL BLENDING
}

\author{
Philippe Dagaut ${ }^{1}$, Yuri Bedjanian ${ }^{1}$, Guillaume Dayma ${ }^{1,2}$, Fabrice Foucher ${ }^{3}$, Benoît Grosselin ${ }^{1}$, \\ Manolis Romanias', Roya Shahla ${ }^{1}$. \\ ${ }^{1}$ CNRS-INSIS,ICARE, 1c Avenue de la Recherche Scientifique, 45071 Orléans, France \\ 2 Université d'Orléans, 6 Avenue du Parc Floral, 45100 Orléans, France \\ ${ }^{3}$ PRISME Université d'Orléans, 8 Rue Léonard de Vinci, 45072 Orléans, France
}

\begin{abstract}
The combustion of conventional fuels (Diesel and Jet A-1) with $10-20 \%$ vol. oxygenated biofuels (ethanol, 1-butanol, methyl octanoate, rapeseed oil methyl ester, diethyl carbonate, tri(propylene glycol)methyl ether, i.e., $\mathrm{CH}_{3}\left(\mathrm{OC}_{3} \mathrm{H}_{6}\right)_{3} \mathrm{OH}$, and 2,5-dimethylfuran) and a synthetic paraffinic kerosene was studied. The experiments were performed using an atmospheric pressure laboratory premixed flame and a four-cylinder four-stroke Diesel engine operating at $1500 \mathrm{rpm}$. Soot samples from kerosene blends were collected above a premixed flame for analysis. Polyaromatic hydrocarbons (PAHs) were extracted from the soot samples. After fractioning, they were analyzed by highpressure liquid chromatography (HPLC) with UV and fluorescence detectors. $\mathrm{C}_{1}$ to $\mathrm{C}_{8}$ carbonyl compounds were collected at the Diesel engine exhaust on 2,4dinitrophenylhydrazine coated cartridges (DNPH) and analyzed by HPLC with UV detection. The data indicated that blending conventional fuels with biofuels has a significant impact on the emission of both carbonyl compounds and PAHs adsorbed on soot. The global concentration of 18 PAHs (1-methylnaphthalene, 2-methyl-naphthalene, and the 16 US priority EPA PAHs) on soot was considerably lowered using oxygenated fuels, except 2,5-dimethylfuran. Conversely, the total carbonyl emission increased by oxygenated biofuels blending. Among them, ethanol and 1-butanol were found to increase considerably the emissions of carbonyl compounds.
\end{abstract}

\section{INTRODUCTION}

Combustion of conventional fuels such as gasoline, Diesel or jet fuels currently used for transportation significantly contributes to greenhouse emissions and global warming [1]. Recently the interest for synthetic and bio-derived fuels [2-10], which are considered helpful for reducing dependence of both air and ground transportation on petroleum [11-13], and environment friendly, increased. The Fischer-Tropsch process allows the production of kerosene or Diesel types of fuel from synthesis gas. Nevertheless, exhaust emissions released into the atmosphere lead to major environmental and health concerns. Some polluting constituents such as carbon monoxide, nitrogen oxides, unburned hydrocarbons, and particulate matter $[14,15]$ are strictly regulated by governments. However, other exhaust constituents, generally referred to as unregulated pollutants, have significant impact on atmospheric pollution and human health. Carbonyl compounds (CBCs) and polyaromatic hydrocarbons (PAHs) are among the important unregulated pollutants emitted from internal combustion engines and gas turbines. Carbonyl compounds, i.e., aldehydes and ketones, can be produced from incomplete combustion of fuels [16] and are of significant importance in atmospheric chemistry [17] through their oxidation and interaction with nitrogen oxides which yield other pollutants, e.g., ozone and peroxyacyl nitrates, lowering urban air quality. In addition to their irritative and ecotoxic properties, some carbonyl compounds such as formaldehyde, acetaldehyde and acrolein are identified as probable or known carcinogen and/or mutagen. Polycyclic aromatics originating principally from incomplete combustion of fossil fuels and other organic matter are present on particulates and in the gas phase. PAHs and their derivatives adsorbed on 
soot have been largely studied due to their potential carcinogenic and/or mutagenic effects, and reactivity in the troposphere. While there is an increasing interest for developing and using biofuels with the aim of reducing dependency to oil, improving engine efficiency and reducing pollutants formation are needed. Oxygenated and synthetic fuels used pure or as additive are potential alternatives to petroleum-based fossil fuels with expected, but not well-assessed, beneficial effects on emissions.

The purpose of this work is to study the impact on pollutants emissions of blending conventional liquid fuels (Jet A-1 and Diesel) with synthetic jet-fuel and oxygenates that can derive from biomass. The pollutants considered are polyaromatic hydrocarbons, ketones and aldehydes. Carbonyls emissions were measured in the exhaust of a Diesel engine running with Diesel and blends. The identification and quantification of PAHs adsorbed on soot were performed using a premixed flame and Jet A-1, easier to handle with a laboratory burner, as reference fuel. Due to the similar composition of Diesel and Jet A-1 fuels, it is expected that there will be no major impact on the interpretation of the present data.

\section{EXPERIMENTAL}

For engine experiments, a conventional Diesel fuel (DF) from Caldeo was used as reference fuel. The other fuels were prepared by blending the DF with $10 \%$ vol. of the following oxygenated additives: ethanol (EtNOL), 1-butanol (1-BNOL), methyloctanoate (MOC), diethylcarbonate (DEC), tri(propylene glycol) methyl ether (TPGME), rapeseed oil methyl ester (RME), and a synthetic paraffinic kerosene (SPK) from Sasol having a derived cetane number of 23 (ASTM D7668). Derived cetane numbers of Diesel fuel and fuel blends tested in engine were measured using a Herzog Cetane ID 510 Analyzer (ASTM D7668); they are given in Table 1 together with the average Filter Smoke Number (FSN) which was continuously measured using an AVL-450s smoke meter in the experiments.

Table 1. Fuel characteristics for engine test.

\begin{tabular}{|c|c|c|}
\hline Fuel & DCN & FSN \\
\hline $\mathrm{DF}$ & 55.34 & 2.35 \\
\hline DF/Ethanol* & 46.32 & 2.01 \\
\hline DF/1-Butanol ${ }^{*}$ & 49.71 & 1.64 \\
\hline $\mathrm{DF} / \mathrm{DEC}^{*}$ & 48.96 & 1.15 \\
\hline $\mathrm{DF} / \mathrm{MOC}^{*}$ & 54.22 & 2.07 \\
\hline DF/TPGME* ${ }^{*}$ & 54.75 & 1.01 \\
\hline DF/SPK ${ }^{*}$ & 52.74 & 2.45 \\
\hline $\mathrm{DF} / \mathrm{RME}^{*}$ & 55.56 & 1.12 \\
\hline
\end{tabular}

* mixture of Diesel fuel/additive $90: 10 \mathrm{v} / \mathrm{v}$
The engine used in this study is a direct-injection 4cylinder 4-stroke Diesel engine with a Continental common-rail injection system. The exhaust gas recirculation rate was set to $32.5 \%$. Experiments were performed at a steady engine operating conditions: $\mathrm{BMEP}=0.75 \mathrm{MPa}(40 \%$ engine load $)$ under a constant speed of $1500 \mathrm{rpm}$. The main engine characteristics are given in Table 2 .

Table 2. Engine characteristics

\begin{tabular}{lc}
\hline Number of cylinders & 4 \\
Bore $(\mathrm{mm})$ & 76 \\
Stroke $(\mathrm{mm})$ & 80.5 \\
Displacement $\left(\mathrm{cm}^{3}\right)$ & 1460.74 \\
Number of injectors & 4 \\
Compression Ratio & 15.21 \\
\hline
\end{tabular}

Before refilling the engine with a new fuel, the connection tubing and fuel tank were drained out and the fuel filter was replaced. Prior to each experiment, the engine was allowed to warm up for $30 \mathrm{~min}$ to ensure the remaining fuel in the system was consumed, and to stabilize the operating parameters. The experiments were repeated at least once. No aftertreatment system was used. Sampling and analysis of CBCs were based on the US EPA TO-11A method [18]. Ten gas samples were collected at $3 \mathrm{~m}$ away from the outlet of the combustion chamber by using an automated sampling device (Figure 1). The exhaust gases were collected on 2,4-dinitrophenylhydrazine (DNPH)-coated silica gel cartridges at a constant sampling flow of $0.5 \mathrm{~L} / \mathrm{min}$ for $5 \mathrm{~min}$. DNPH reacts with carbonyls to form the corresponding stable dinitrophenylhydrazone derivatives that are quantified. At the aforementioned sampling distance from the engine, the gas temperature is low enough (ca. $60^{\circ} \mathrm{C}$ ) to avoid damaging DNPH or the carbonyls derivatives. In order to minimize errors due to the variation of sampling flow rate, ten samples were collected for each fuel, and the average values were used.

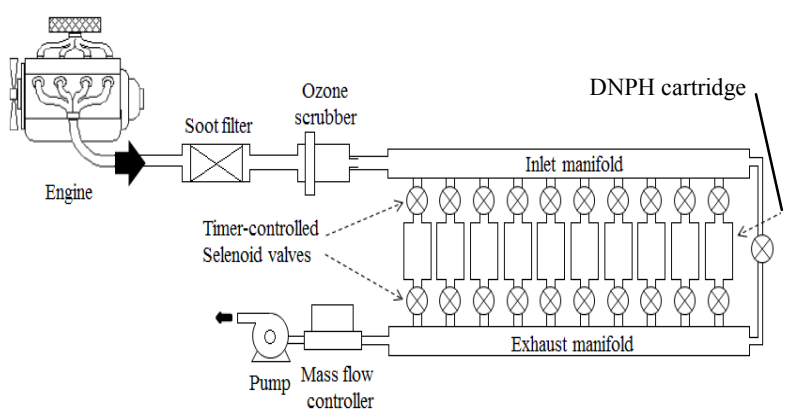

Figure 1. Schematic representation of the CBCs sampling system used from engine measurements. 
After sampling, the cartridges were slowly eluted with $5.0 \mathrm{~mL}$ acetonitrile and the extracts were labeled and stored at $4{ }^{\circ} \mathrm{C}$. The samples containing the carbonyl-DNPH derivatives were then analyzed by high-performance liquid chromatography. HPLC grade acetonitrile (ACN), water and tetrahydrofuran (THF) were employed as mobile phase. The following gradient elution was adopted for ACN/water/THF: 0$12 \mathrm{~min}$ at $40: 55: 5 \mathrm{v} / \mathrm{v} / \mathrm{v}$ and a flow rate of $1.0 \mathrm{~mL} / \mathrm{min}$ followed by a linear gradient to 55:40:5 v/v/v until 35 $\mathrm{min}$ and a flow rate of $1.5 \mathrm{~mL} / \mathrm{min}$, and held at 55:40:5 $\mathrm{v} / \mathrm{v} / \mathrm{v}$ until $50 \mathrm{~min}$ with a flow rate of $1.5 \mathrm{~mL} / \mathrm{min}$. The sample injection volume and column temperature were $20 \mu \mathrm{L}$ and $40{ }^{\circ} \mathrm{C}$, respectively. The carbonyls detection wavelength was set to $360 \mathrm{~nm}$. The identification and quantification of $\mathrm{CBCs}$ were performed using a DNPH-carbonyl standard containing 13 carbonyl compounds: formaldehyde, acetaldehyde, acrolein, acetone, propionaldehyde, crotonaldehyde, methacrolein, 2-butanone, n-butyraldehyde, benzaldehyde, valeraldehyde, p-tolualdehyde, and hexanal.

Table 3. Fuel characteristics for burner experiments.

\begin{tabular}{ll}
\hline Fuel & $\mathrm{O} / \mathrm{C}$ in fuel \\
\hline 1: Jet A-1 & 0.0 \\
2: SPK & 0.0 \\
3: Jet A-1/1-Butanol & 0.040 \\
4: Jet A-1/DEC & 0.092 \\
5: Jet A-1/MOC & 0.040 \\
6: Jet A-1/2,5-DMF & 0.033 \\
\hline
\end{tabular}

For premixed flat-flame burner experiments, a conventional aviation jet fuel (Jet A-1) with a derived cetane number of 44.7 (ASTM D7668) was used as reference fuel. Four fuel blends were prepared by adding $20 \%$ by volume of the following oxygenated additives to Jet A-1: 1-butanol, methyl octanoate, diethyl carbonate, 2,5-dimethylfuran, and a synthetic paraffinic kerosene from Sasol. A laboratory flat-flame burner was used for the production and deposition of soot samples from premixed flames of liquid fuels (Jet A-1 and fuel blends) in a reproducible way and under well-characterized and controlled combustion conditions [19]. The soot samples were produced under fuel-rich condition $(\varphi \approx 2.3)$ and deposited on the outer surface of a Pyrex tube. The collection tube was introduced perpendicular to the flame axis at the height of $4 \mathrm{~cm}$ above the head of the burner and was rotated and moved through the flame by operator. The flame was isolated from environment atmosphere with a cylindrical Pyrex tube through which a nitrogen flow was introduced from the small orifices creating a pressure lightly higher than atmospheric pressure. This avoids the air diffusion and helps to have a homogeneous and stabilized flame. The sampling Pyrex tube was thermostated at $45^{\circ} \mathrm{C}$ by an internal water circulation in order to prevent surface temperature gradient and ensure a homogeneous distribution of PAHs along the tube (Figure 2).

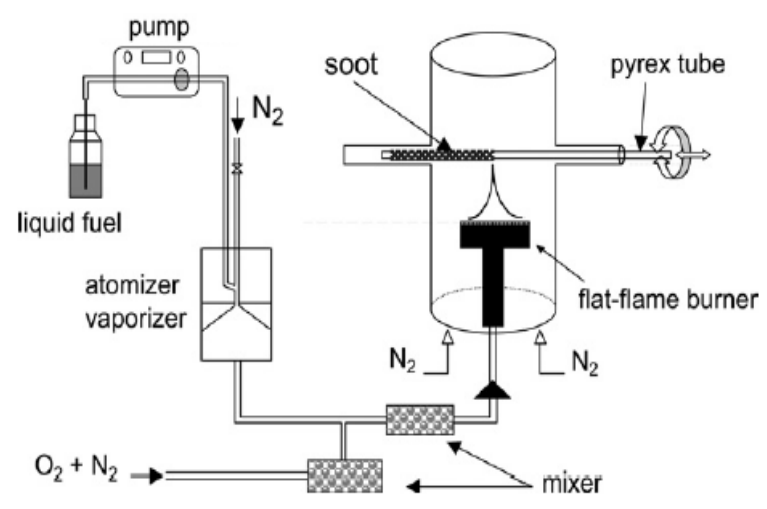

Figure 2. Schematic representation of the apparatus used for soot production and deposition.

The deposited soot was removed mechanically, weighed, and introduced into $2 \mathrm{~mL}$ of HPLC-grade $\mathrm{n}$ hexane (Sigma Aldrich with stated purity $\geq 97 \%$ ). The soot extracts were filtered twice using hydrophobic PTFE filter (pore size $0.2 \mu \mathrm{m}$ by Alltech) to remove the non-soluble fraction mostly containing carbonaceous material. The resulting soot extracts were analyzed using a Shimadzu HPLC system leading to identification and quantification of PAHs and their derivatives [20]. The HPLC system was equipped with a C18 column (Grace Vydac 201TP, $250 \mathrm{~mm} \times 4.6 \mathrm{~mm} \times 5 \mu \mathrm{m}$ ), an automatic injector, and a photodiode array detector. Acetonitrile and water were used as mobile phase with the elution program: 0-30 $\mathrm{min}$ at $50: 50 \mathrm{v} / \mathrm{v}$ followed by a linear gradient to $100 / 0 \mathrm{v} / \mathrm{v}$ at $90 \mathrm{~min}$, and remained at $100 / 0 \mathrm{v} / \mathrm{v}$ until $110 \mathrm{~min}$. The flow rate and column temperature were $0.5 \mathrm{~mL} / \mathrm{min}$ and $30{ }^{\circ} \mathrm{C}$, respectively. A certified 18 EPA PAHs standard $(2000 \mu \mathrm{g} / \mathrm{mL}$ of each, Supelco) was used for identifying and quantifying naphthalene, 1-methylnaphthalene, 2-methylnaphthalene, acenaphthylene, acenaphthene, fluorene, phenanthrene, anthracene, fluoranthene, pyrene, benzo[a]anthracene, chrysene, benzo[b]fluoranthene, benzo[k]fluoranthene, benzo[a]pyrene, dibenzo[a,h] anthracene, benzo $[\mathrm{g}, \mathrm{h}, \mathrm{i}]$ perylene, and indeno[ $[1,2,3-\mathrm{c}, \mathrm{d}]$ pyrene.

\section{RESULTS AND DISCUSSION}

\section{Engine results}

Thirteen carbonyl compounds were identified and quantified in exhaust emissions of a four-cylinder four-strike Diesel engine running at a stabilized 
operating point with conventional DF and 7 blends (10\% by volume of biofuels or SKP to limit the impact on engine operating conditions such as combustion phasing).

The measured total CBCs emissions are shown in Figure 3. The total concentration of carbonyl compounds obtained for the Diesel fuel was close to 1 $\mathrm{mg} \mathrm{m}^{-3}$. Based on our results, blending DF with RME and SPK has no major effect on the emission of carbonyl compounds. However, blending DF with ethanol, 1-butanol, diethylcarbonate, methyloctanoate, and TPGME increases significantly the concentrations carbonyl compounds in exhaust gases. Here, the highest $\mathrm{CBCs}$ content was measured for the DF/Ethanol blend $\left(3.87 \mathrm{mg} \mathrm{m}^{-3}\right)$.

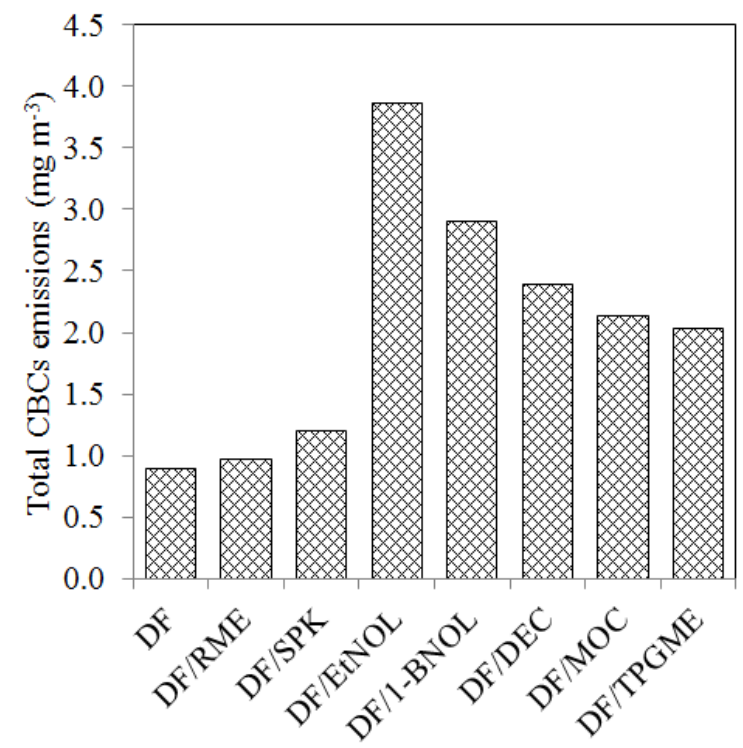

Figure 3. Total emission of carbonyl compounds.

Carbonyl compounds contribution in exhaust emissions is shown in Figure 4. Under the operating conditions applied in this study, acetaldehyde was the most abundant carbonyl compound measured in the exhausts, for all fuels. Acetaldehyde emissions were in the range $0.32-1.72 \mathrm{mg} \mathrm{m}^{-3}$, which corresponds to 33 $45 \%$ of the mass of carbonyl compounds in exhaust gases. In addition, the concentration of acetaldehyde in exhaust emissions is higher than formaldehyde for all fuels. Formaldehyde, with a highest contribution of 0.3 $\mathrm{mg} \mathrm{m}^{-3}$, is the second most abundant carbonyl compound found after acetaldehyde. It represents 6$14 \%$ of the total mass of carbonyl compounds in exhaust gases. The emissions of individual carbonyl compounds are presented in Figure 5.

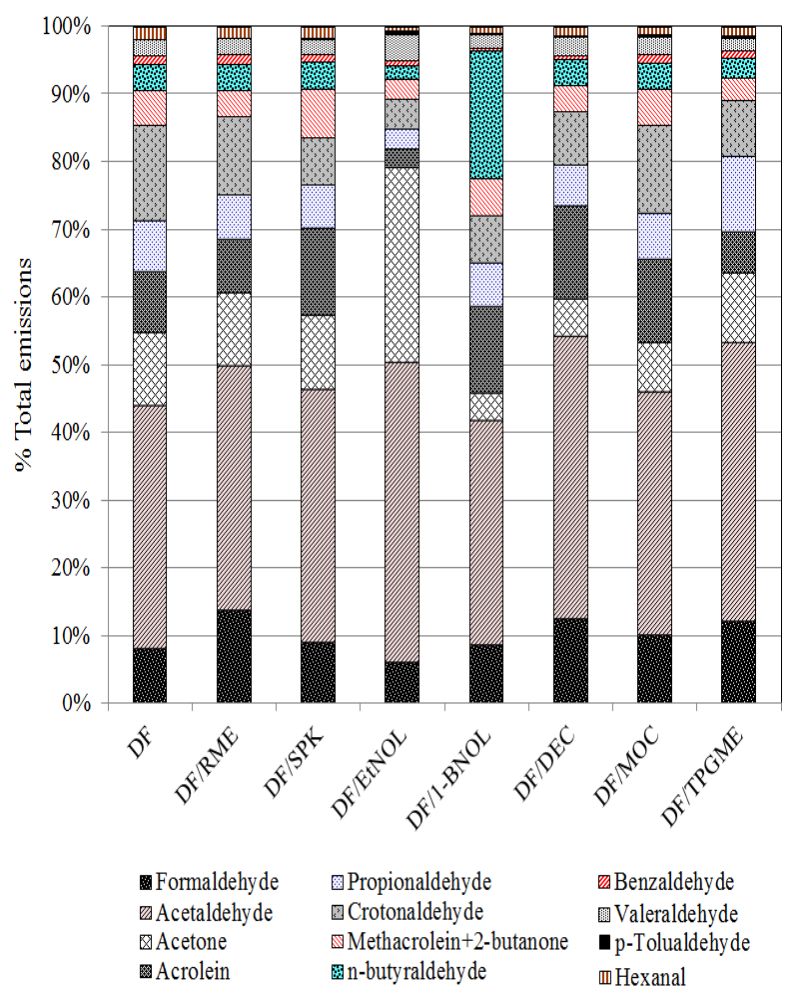

Figure 4. Contribution of each carbonyl compound to total emissions of the fuels considered here.

As shown in Figure 5-(a), acetaldehyde is the major component among carbonyls followed by formaldehyde and acrolein. However, one should note that the measured concentrations of carbonyl compounds are very low (less than $1 \mathrm{ppm}$ ). A global uncertainty of $\pm 25 \%$ was estimated. Acetone, propionaldehyde, and crotonaldehyde were also emitted in significant quantities, but their concentrations were below those of the three major compounds cited above. Similar results have been reported by Guarieiro et al.[21] for carbonyl compounds emitted by a Diesel engine operating under similar conditions (1800 or 2000 ppm).

Formaldehyde and acetaldehyde emissions increased for all blended fuels. The highest emissions of formaldehyde $(0.223 \mathrm{ppm})$ and acetaldehyde $(0.874$ ppm) were measured for the DF/DEC blend and the $\mathrm{DF} /$ Ethanol blend, respectively.

Regarding the DF/Ethanol blend, formaldehyde, acetaldehyde and acetone were the most abundant carbonyls. Similar results regarding the increase of formaldehyde and acetaldehyde emissions by adding ethanol to Diesel fuel have been reported by Song et al. [22], and Cheung et al. [23]. 
(a)

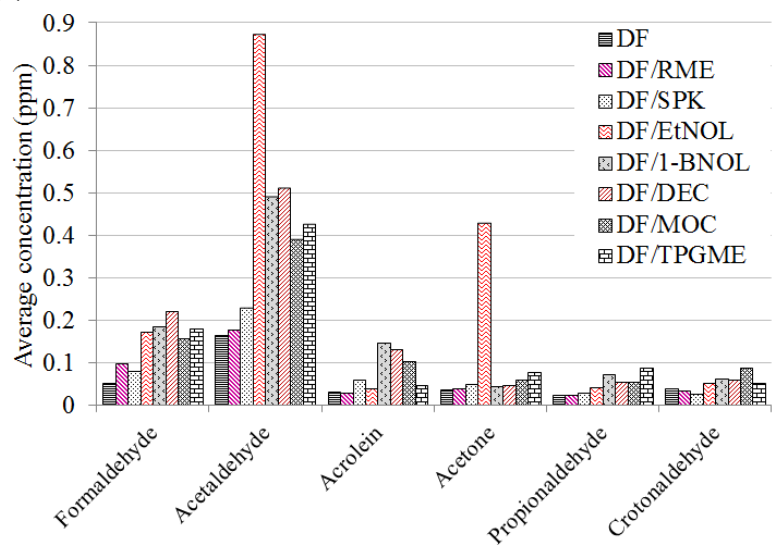

(b)

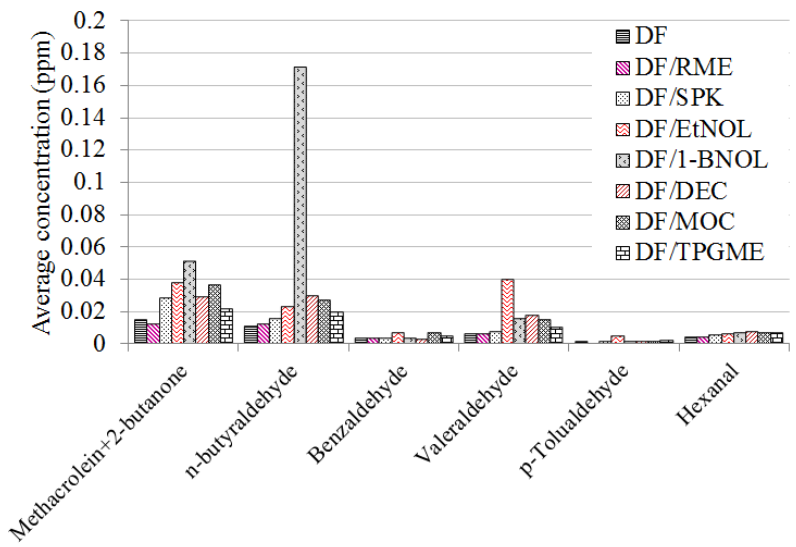

Figure 5. Individual carbonyl compounds emissions from the different fuels tested.

The partial combustion of the fuel and the presence of ethanol as the main precursor of acetaldehyde $\left(\mathrm{CH}_{3} \mathrm{CH}_{2} \mathrm{OH}+{ }^{\bullet} \mathrm{OH} \rightarrow \mathrm{CH}_{3}{ }^{\bullet} \mathrm{CHOH} \rightarrow \mathrm{CH}_{3} \mathrm{CHO}\right)$ can explain the high concentrations of formaldehyde and acetaldehyde [24]. As proposed by Tao et al.[25], the degradation of acetaldehyde can result in the formation of $\mathrm{CH}_{3}{ }^{\circ} \mathrm{CO}$ that can lead to the formation of acetone via:

$$
\mathrm{CH}_{3}{ }^{\bullet} \mathrm{CO}+{ }^{\bullet} \mathrm{CH}_{3} \rightarrow \mathrm{CH}_{3} \mathrm{COCH}_{3}
$$

Concerning the DF/DEC blend, acetaldehyde was again the most abundant carbonyl emitted, followed by formaldehyde. Such important quantity for acetaldehyde is consistent with experimental results obtained from the oxidation of diethyl carbonate in a jet-stirred reactor [26] where acetaldehyde formation can result from:

$\left(\mathrm{CH}_{3} \mathrm{CH}_{2} \mathrm{O}\right)_{2} \mathrm{C}=\mathrm{O} \rightarrow \mathrm{CH}_{3} \mathrm{CH}_{2} \mathrm{O}^{\bullet} \rightarrow \mathrm{CH}_{3} \mathrm{CHO}$
$\left(\mathrm{CH}_{3} \mathrm{CH}_{2} \mathrm{O}\right)_{2} \mathrm{C}=\mathrm{O} \rightarrow \mathrm{CO}_{2}+\mathrm{C}_{2} \mathrm{H}_{4}+\mathrm{CH}_{3} \mathrm{CH}_{2} \mathrm{OH}$

$\mathrm{CH}_{3} \mathrm{CH}_{2} \mathrm{OH}+{ }^{\bullet} \mathrm{OH} \rightarrow \mathrm{CH}_{3}{ }^{\bullet} \mathrm{CHOH} \rightarrow \mathrm{CH}_{3} \mathrm{CHO}+\mathrm{H}^{\bullet}$

Figure 5-(b) focuses on other carbonyls (methacrolein, 2-butanone, n-butyraldehyde, benzaldehyde, valeraldehyde, p-tolualdehyde and hexanal) which were present in the exhaust emissions but in much lower concentrations. High emissions of nbutyraldehyde and 2-butanone were observed with the DF/1-Butanol blend. The presence of the decomposition products of 1-butanol in the reaction zone could result in the formation of these two carbonyl compounds:

$$
\begin{aligned}
& \mathrm{CH}_{3}\left(\mathrm{CH}_{2}\right)_{3} \mathrm{OH}+\mathrm{X} \rightarrow \mathrm{CH}_{3}\left(\mathrm{CH}_{2}\right)_{2}{ }^{\bullet} \mathrm{CHOH}+\mathrm{XH} \\
& \mathrm{CH}_{3}\left(\mathrm{CH}_{2}\right)_{3} \mathrm{OH}+\mathrm{X} \rightarrow \mathrm{CH}_{3} \mathrm{CH}^{\bullet} \mathrm{CH}_{2} \mathrm{CH}_{2} \mathrm{OH}+\mathrm{XH}
\end{aligned}
$$

which can in turn yield n-butyraldehyde and 2butanone. $n$-Butyraldehyde is formed via:

$$
\mathrm{CH}_{3}\left(\mathrm{CH}_{2}\right)_{2}{ }^{\bullet} \mathrm{CHOH} \rightarrow \mathrm{CH}_{3}\left(\mathrm{CH}_{2}\right)_{2} \mathrm{CHO}+\mathrm{H}
$$

The formation of 2-butanone can derive from the lowtemperature oxidation of 1-butanol triggered by that of the Diesel fuel (with multiple oxygen addition to fuelderived radicals, internal hydrogen transfer, and decomposition, followed by recombination of ${ }^{\bullet} \mathrm{CH}_{3}$ and $\left.\mathrm{CH}_{3}(\mathrm{CO})^{\bullet} \mathrm{CH}_{2}\right)$ :

$$
\begin{array}{r}
\mathrm{CH}_{3}{ }^{\bullet} \mathrm{CHCH}_{2} \mathrm{CH}_{2} \mathrm{OH}\left(+2 \mathrm{O}_{2}+\mathrm{CH}_{3}\right) \rightarrow \\
\mathrm{CH}_{3} \mathrm{C}(\mathrm{O}) \mathrm{CH}_{2} \mathrm{CH}_{3}\left(+{ }^{\bullet} \mathrm{OH}+\mathrm{HCOOH}\right)
\end{array}
$$

The seven carbonyls shown in Figure 5-(b) contribute to $10-28 \%$ of the total emissions.

\section{Premixed flame results}

The soot particulates were produced and collected using an atmospheric pressure premixed flame of Jet A-1, SPK, and four biofuel-Jet A-1 blends under fuelrich conditions $(\varphi \approx 2.3)$. The soluble PAHs fractions were extracted and analyzed by HPLC system using a recently validated analytical methodology [20]. Based on our first observations on premixed flame, the sooting tendency of fuels can be assumed proportional to soot collection rates defined as the total mass of soot particulate deposited in time. One should note that this trend cannot be simply estimated from the $\mathrm{O} / \mathrm{C}$ ratio in the fuel (Table 3) because it depends strongly on the fuel chemical structure [27-29]. Indeed, blends containing 1-butanol or methyl octanoate produce significantly different amounts of soot whereas they have the same $\mathrm{O} / \mathrm{C}$ ratio, which is in 
line with earlier findings showing alcohols are more efficient to reduce soot than esters [14].

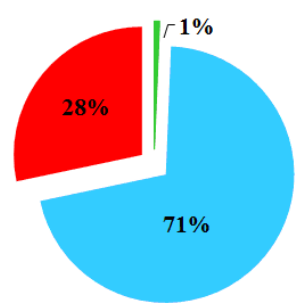

Jet A-1/2,5-DMF

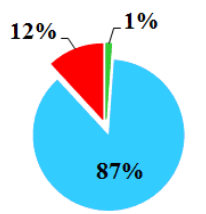

Jet A-1/DEC

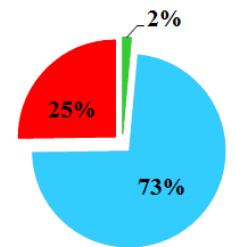

Jet A-1/OctM

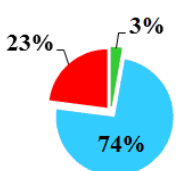

Jet A-1/1-BNOL

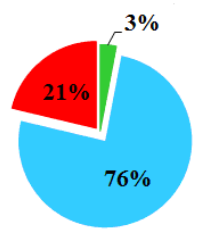

Jet A-1

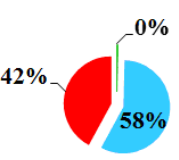

SPK

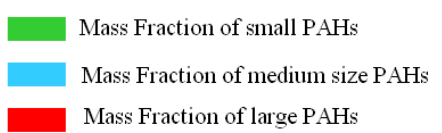

Figure 6. PAHs relative abundance in the analyzed soot extracts. Small PAHs: $\mathrm{MW}=128.17-166.22$ $\mathrm{g} / \mathrm{mol}$; Medium PAHs: MW $=178.23-228.29 \mathrm{~g} / \mathrm{mol}$; Large PAHs: $\mathrm{MW}=252.31-276.33 \mathrm{~g} / \mathrm{mol}$.

The relative sooting tendencies derived here from this assumption were: 1 for Jet A-1, 0.33 for SPK, 0.37 for Jet A-1/1-butanol, 0.50 for Jet A-1/DEC, 1.17 for Jet A-1/Methyloctanoate, and 1.77 for Jet A-1/2,5dimethylfuran (2,5-DMF). Table 4 shows the measured absolute concentrations of the 16 US EPA priority PAHs present on soot sample. The total PAHs concentration varied from 250 to $4700 \mathrm{ng} \mathrm{mg}^{-1}$.

Table 4. Summary of PAHs measurements.

\begin{tabular}{|c|c|}
\hline Fuel & $\begin{array}{l}\text { Total } 18 \text { EPA PAHs } \\
\text { (ng mg-1 of soot) }\end{array}$ \\
\hline 1 Jet A-1 & 3551 \\
\hline 2: SPK & 3412 \\
\hline 3: Jet A-1/1-Butanol & 253 \\
\hline 4: Jet A-1/DEC & 1978 \\
\hline 5: Jet A-1/MOC & 819 \\
\hline 6: Jet A-1/2,5-DMF & 4662 \\
\hline
\end{tabular}

Conventional Jet A-1 and SPK yielded similar PAHs content (3551 and $3412 \mathrm{ng} \mathrm{mg}^{-1}$, respectively). Much higher PAHs content was observed for the Jet A-1/2,5DMF blend (4662 $\mathrm{ng} \mathrm{mg}^{-1}$ of soot). If we apply fuel sooting tendencies on the values presented in Table 4, we can obtain the following trend on total PAHs content for the tested fuel blends: Jet A-1/2,5-DMF > Jet A-1 $>$ SPK $>$ Jet A-1/DEC $>$ Jet A-1/MOC $>$ Jet A-
1/1-Butanol. Therefore, excluding the Jet A-1/2,5DMF blend, the addition of oxygenated biofuels to Jet A-1 reduces considerably the emissions of soot absorbed PAHs.

Table 5. Global toxicity of soot samples*

\begin{tabular}{lcr}
\hline Fuel & $\begin{array}{c}\text { Equivalent } \\
\text { toxicity (TEQ)* }\end{array}$ & $\begin{array}{r}\text { Variation to } \\
\text { Jet A-1 \% }\end{array}$ \\
\hline Jet A-1/1-Butanol & 1.29 & -99 \\
Jet A-1/DEC & 10.83 & -94 \\
Jet A-1/MOC & 83.98 & -57 \\
SPK & 115.90 & -40 \\
Jet A-1 & 193.57 & 0 \\
Jet A-1/2,5-DMF & 574.14 & +197 \\
\hline$*$ calculated global & equivalent toxicity & according to \\
[30]. &
\end{tabular}

The lowest PAHs content was obtained for Jet A-1/1Butanol blend. Based on our results, the contribution of polyaromatics with different molecular weight (between 125-280 $\mathrm{g} \mathrm{mol}^{-1}$ ) differs from one soot sample to another. Figure 6 gives the relative abundance of PAHs on soot; the size of the disks is proportional to the quantity of soot produced. Figure 6 shows that light PAHs (with 2 aromatic rings) represents only $3 \%$ or less of the total mass of PAHs quantified, while medium size PAHs (with 3-4 aromatic rings) constitute more than $58 \%$. The highest concentration of heavy polyaromatics $(\geq 5$ aromatic rings) was observed for SPK (lowest sooting tendency) with $42 \%$ of the mass of soot collected whereas it reached only $28 \%$ of soot collected mass for the Jet A-1/2,5-DMF blend which has the highest sooting tendency.

Global toxicity of soot samples was calculated based on the work of Nisbet and Lagoy [30] that consider the individual toxicity of PAHs. The present work indicates (Table 5) that global toxicity of soot increases when Jet A-1 is blended with 1,2-DMF whereas for other blends, it decreases. Toxicity of soot particulates follows the trend: Jet A-1/2,5-DMF $>$ Jet A-1 $>$ SPK $>$ Jet A-1/MOC $>$ Jet A-1/DEC $>$ Jet A1/1-Butanol. Such impact of fuel blending, based solely on PAHs content, needs to be confirmed by direct test such as in vitro experiments.

\section{CONCLUSION}

In this work, we investigated the effect of blending conventional fuels (Diesel and Jet A-1) with oxygenated or synthetic fuels that can be derived from biomass. Carbonyl compounds emission and soot surface-bounded PAHs contents were measured using a four-cylinder Diesel engine and a premixed flame burner, respectively. The results indicated no 
correlation between oxygen content of the fuel blends and sooting tendency, PAHs concentrations, or carbonyls emissions. The global concentration of PAHs on soot was considerably lowered using oxygenated fuels, except 2,5-DMF. The lowest PAHs content was found for the 1-butanol-Jet A-1 blend. Conversely, the total carbonyl emission increased when oxygenated biofuels were added to the reference Diesel fuel. Ethanol and 1-butanol were found to increase considerably the emissions of carbonyl compounds. In all samples, acetaldehyde and pyrene were the most abundant compounds among carbonyl and polycyclic aromatic compounds, respectively. This study shows that blending conventional fuels with synthetic fuels does not imply a reduction of pollutants emission nor soot toxicity reduction.

\section{ACKNOWLEDGMENTS}

This work received funding from the European Research Council under the European Community's 7th Framework Programme (FP7/2007-2013) / ERC grant agreement $n^{\circ}$ 291049-2G-CSafe. The authors are grateful to J. Lemaire and F. Peyroux for technical assistance.

\section{NOMENCLATURE}

$\varphi: \quad$ Equivalence ratio

BMEP : Brake Mean Effective Pressure

CBs: Carbonyl compounds

DCN: Derived cetane number, ASTM D7668

DF: Diesel fuel

DNPH: 2,4-dinitro phenylhydrazine

HPLC: High pressure liquid chromatography

MW: molecular weight

PAHs: Polyaromatic hydrocarbons

PTFE: Polytetrafluoroethylene

RPM: rotation per minute

SPK: Synthetic paraffinic kerosene

UV: Ultra-violet

\section{REFERENCES}

[1] Sawyer, R. F., 2009, "Science based policy for addressing energy and environmental problems," Proc. Combust. Inst., 32(1), pp. 45-56.

[2] Escobar, J. C., Lora, E. S., Venturini, O. J., Yáñez, E. E., Castillo, E. F., and Almazan, O., 2010, "Biofuels: Environment, technology and food security," Renewable and Sustainable Energy Reviews, 13(6-7), pp. 1275-1287.

[3] European-Commission., 2011, "Biofuels flight path.,"

http://ec.europa.eu/energy/renewables/biofuels/do c/20110622 biofuels flight path technical pape r.pdf.
[4] Mzé Ahmed, A., Dagaut, P., Hadj-Ali, K., Dayma, G., Kick, T., Herbst, J., Kathrotia, T., BraunUnkhoff, M., Herzler, J., Naumann, C., and Riedel, U., 2012, "The Oxidation of a Coal-toLiquid Synthetic Jet Fuel: Experimental and Chemical Kinetic Modeling Study," Energy Fuels, 26(10), p. 6070-6079.

[5] Dagaut, P., Dayma, G., Dievart, P., Hadj-Ali, K., and Mze-Ahmed, A., 2014, "Combustion of a Gas-to-Liquid-Based Alternative Jet Fuel: Experimental and Detailed Kinetic Modeling," Combust. Sci. Technol., 186(10-11), pp. 12751283.

[6] Dagaut, P., Karsenty, F., Dayma, G., Diévart, P., Hadj-Ali, K., Mzé-Ahmed, A., Braun-Unkhoff, M., Herzler, J., Kathrotia, T., Kick, T., Naumann, C., Riedel, U., and Thomas, L., 2014, "Experimental and detailed kinetic model for the oxidation of a Gas to Liquid (GtL) jet fuel," Combust. Flame, 161(3), pp. 835-847.

[7] Dagaut, P., Dayma, G., Karsenty, F., and Serinyel, Z., "The Combustion of Synthetic Jet Fuels (Gas to Liquid and Coal to Liquid) and MultiComponent Surrogates: Experimental and Modeling Study GT2015-42004," Proc. ASME Turbo Expo 2015: Turbine Technical Conference and Exposition, ASME, p. V003T003A001.

[8] Mze-Ahmed, A., Dagaut, P., Dayma, G., and Dievart, P., 2015, "Kinetics of Oxidation of a 100\% Gas-to-Liquid Synthetic Jet Fuel and a Mixture GtL/1-Hexanol in a Jet-Stirred Reactor: Experimental and Modeling Study," J. Eng. Gas Turbines Power-Transact. of the Asme, 137(1), pp. 11503-11503.

[9] Dagaut, P., Karsenty, F., Dayma, G., and Serinyel, Z., 2016, "Experimental and Kinetic Modeling of the Oxidation of Synthetic Jet Fuels and Surrogates," Combust. Sci. Technol., 188(11-12), pp. $1705-1718$.

[10] Dagaut, P., and Dievart, P., 2017, "Combustion of synthetic jet fuels: Naphthenic cut and blend with a gas-to-liquid (GtL) jet fuel," Proc. Combust. Inst., 36(1), pp. 433-440.

[11] Hermann, F., Klingmann, J., Gabrielsson, R., Pedersen, J. R., Olsson, J. O., and Owrang, F., "Chemical analysis of combustion products from a high-pressure gas turbine combustor rig fueled by jet A1 fuel and a Fischer-Tropsch-based fuel," Proc. ASME Turbo Expo 2006, Vol 1, ASME, pp. 523-532.

[12] Corporan, E., DeWitt, M. J., Belovich, V., Pawlik, R., Lynch, A. C., Gord, J. R., and Meyer, T. R., 2007, "Emissions characteristics of a turbine engine and research combustor burning a 
Fischer-Tropsch jet fuel," Energy Fuels, 21(5), pp. 2615-2626.

[13] Huber, M. L., Smith, B. L., Ott, L. S., and Bruno, T. J., 2008, "Surrogate mixture model for the thermophysical properties of synthetic aviation fuel S-8: Explicit application of the advanced distillation curve," Energy Fuels, 22(2), pp. 11041114.

[14] Buchholz, B. A., Mueller, C. J., Upatnieks, A., Martin, G. C., Pitz, W. J., and Westbrook, C. K., 2004, "Using Carbon-14 Isotope Tracing to Investigate Molecular Structure Effects of the Oxygenate Dibutyl Maleate on Soot Emissions from a DI Diesel Engine," SAE International.

[15] Ratcliff, M. A., Burton, J., Sindler, P., Christensen, E., Fouts, L., Chupka, G. M., and McCormick, R. L., 2016, "Knock Resistance and Fine Particle Emissions for Several Biomass-Derived Oxygenates in a Direct-Injection Spark-Ignition Engine," SAE Int. J. Fuels Lubr., 9(1), pp. 59-70.

[16] Ratcliff, M. A., Luecke, J., Williams, A., Christensen, E., Yanowitz, J., Reek, A., and McCormick, R. L., 2013, "Impact of Higher Alcohols Blended in Gasoline on Light-Duty Vehicle Exhaust Emissions," Environmental Science \& Technology, 47(23), pp. 13865-13872.

[17] Seinfeld, J. H., and Pandis, S. N., 2006, Atmospheric Chemistry and Physics: From Air Pollution to Climate Change, Wiley-Interscience, Hoboken, NJ.

[18] US-EPA, 1999, "Compendium method TO-11A: Determination of formaldehyde in ambient air using adsorbent cartridge followed by high performance liquid chromatography (HPLC) [Active sampling methodology], EPA/625/R96/010b."

[19] Lelièvre, S., Bedjanian, Y., Pouvesle, N., Delfau, J.-L., Vovelle, C., and G., L. B., 2004, "Heterogeneous reaction of ozone with hydrocarbon flame soot," Phys. Chem. Chem. Phys., 6(6), pp. 1181-1191.

[20] Andrade-Eiroa, A., Shahla, R., Romanias, M. N., and Dagaut, P., 2014, "An alternative to trial and error methodology in solid phase extraction: an original automated solid phase extraction procedure for analysing PAHs and PAHderivatives in soot," Rsc Advances, 4(63), pp. 33636-33644.

[21] Guarieiro, L. L. N., de Souza, A. F., Torres, E. A., and de Andrade, J. B., 2009, "Emission profile of 18 carbonyl compounds, $\mathrm{CO}, \mathrm{CO} 2$, and $\mathrm{NOx}$ emitted by a diesel engine fuelled with diesel and ternary blends containing diesel, ethanol and biodiesel or vegetable oils," Atmos. Environ., 43(17), pp. 2754-2761.
[22] Song, C., Zhao, Z., Lv, G., Song, J., Liu, L., and Zhao, R., 2010, "Carbonyl compound emissions from a heavy-duty diesel engine fueled with diesel fuel and ethanol-diesel blend," Chemosphere, 79(11), pp. 1033 - 1039.

[23] Cheung, C., Di, Y., and Huang, Z., 2008, "Experimental investigation of regulated and unregulated emissions from a diesel engine fueled with ultralow-sulfur diesel fuel blended with ethanol and dodecanol," Atmos. Environ., Part A, 42(39), pp. 1352-2310.

[24] Agarwal, A. K., 2007, "Biofuels (alcohols and biodiesel) applications as fuels for internal combustion engines," Prog. Energy Combust. Sci., 33(3), pp. 233-271.

[25] Tao, T., Sun, W., Yang, B., Hansen, N., Moshammer, K., and Law, C. K., 2017, "Investigation of the chemical structures of laminar premixed flames fueled by acetaldehyde," Proc. Combust. Inst., 36(1), pp. 1287-1294.

[26] Shahla, R., Togbe, C., Thion, S., Timothee, R., Lailliau, M., Halter, F., Chauveau, C., Dayma, G., and Dagaut, P., 2017, "Burning velocities and jet-stirred reactor oxidation of diethyl carbonate," Proc. Combust. Inst., 36(1), pp. 553560.

[27] McEnally, C. S., and Pfefferle, L. D., 2005, "Fuel decomposition and hydrocarbon growth processes for oxygenated hydrocarbons: butyl alcohols," Proc. Combust. Inst., 30, pp. 13631370.

[28] McEnally, C. S., and Pfefferle, L. D., 2011, "Sooting Tendencies of Oxygenated Hydrocarbons in Laboratory-Scale Flames," Environmental Science \& Technology, 45(6), pp. 2498-2503.

[29] Pepiot-Desjardins, P., Pitsch, H., Malhotra, R., Kirby, S. R., and Boehman, A. L., 2008, "Structural group analysis for soot reduction tendency of oxygenated fuels," Combust. Flame, 154(1-2), pp. 191-205.

[30] Nisbet, I. C. T., and Lagoy, P. K., 1992, "Toxic equivalency factors (TEFS) for polycyclic aromatic-hydrocarbons (PAHs)," Regulatory Toxicology and Pharmacology, 16(3), pp. 290300. 